\title{
Evaluation of the activity of thermostable DNA polymerases in the presence of heme, as a key inhibitor in the real time PCR method in diagnostics of sepsis
}

\author{
Tomasz Gosiewski ${ }^{凶}$, Monika Brzychczy-Włoch, Agata Pietrzyk, Agnieszka Sroka and \\ Małgorzata Bulanda
}

Chair of Microbiology, Jagiellonian University Medical College, Kraków, Poland

\begin{abstract}
The study aim was evaluation of the usefulness of several thermostable DNA polymerases in real time PCR conducted in the presence of the heme. Our study had the advantage of testing several different polymerases, one of which proved to be the least sensitive to heme activity. We also found that there is no need of supplementing the reaction mixture with protective substances like BSA. Selection of the appropriate polymerase can increase the efficiency of the PCR reaction which is very important for diagnosis of sepsis and for other analyses performed on DNA template isolated from the blood.
\end{abstract}

Key words: polymerase inhibitor, heme, real time PCR, sepsis

Received: 06 June, 2013; revised: 08 October, 2013; accepted: 12 November, 2013; available on-line: 17 December, 2013

\section{INTRODUCTION}

Performing PCR on DNA isolated from blood may reduce the sensitivity of the assay, or even result in obtaining false negative results. The problem is caused by the the presence of heme, which is a very strong inhibitor of DNA polymerase enzymes used in the PCR method (Al-Soud et al., 1998; Opel et al., 2010).

Serious medical problems are posed by bacterial and fungal infections. The most dangerous of these are systemic infections, such as sepsis, which constitutes one of the most urgent issues of modern medicine. Efficient microbiological diagnostics facilitates quick (within the first hours after clinical diagnosis) employment of targeted antimicrobial treatment, which may contribute to reducing patient mortality caused by blood infections and significantly lowering the costs of hospitalization. The sensitivity of molecular methods considerably exceeds the sensitivity of culture methods. Moreover, previous application of antibiotherapy does not influence test results because there is no need to obtain bacterial or fungal growth on culture medium but only to detect their DNA (Klouche \& Schroder, 2008). Unfortunately, the methods of molecular biology encounter limitations when applied to microbiological diagnostics of blood. Many available procedures for blood processing do not allow the elimination of the inhibitory effect of heme on polymerase activity, which in consequence, leads to obtaining false negative results (Akane et al., 1994).

Literature offers various reports regarding numerous ways of sample processing so that the PCR inhibition effect can be eliminated. These are usually procedures involving thorough sample washing, dilution, or an ad- dition of a substance to the reaction mixture, e.g. bovine albumin (BSA), glycerol, or dextran, which constitute an additional target for the inhibitors and decrease their impact on DNA polymerase (Akane et al., 1994). Attempts have also been undertaken to select a specific polymerase from a series of thermostable DNA polymerases used in PCR (Taq, Pwo, Pfu, Tfl and others) which have different sensitivity to the activity of inhibitors (Al-Soud et al., 1998).

The objective of the study was to assess the usefulness of several thermostable DNA polymerases in the presence of heme.

\section{MATERIALS AND METHODS}

Microbial strains and DNA. Escherichia coli ATCC 25922 (American Type Culture Collection). E. coli DNA and DNA from human blood were isolated using the GeneMATRIX Quick Blood DNA Purification Kit (EURx) according to producer`s protocol.

Patients. $1.5 \mathrm{ml}$ blood samples were collected from volunteers, who had no clinical symptoms of sepsis and no inflammatory markers (CRP, OB). Blood samples were drawn into 2-ml Vacutainer $\mathrm{K}_{3} \mathrm{E}$ (BectonDickinson) test tubes. The research was granted approval by the local Bioethics Committee of the Jagiellonian University (KBET/94/B/2009).

DNA amplification. All reactions of DNA amplification were performed with the use of the real-time PCR method (rtPCR) in a CFX96 thermocycler (BioRad) by using E. coli specific starters and TaqMan probe: (F) GGGAGTAAAGTTAATACCTTTGC, (R) CTCAAGCTTGCCAGTAT CAG, FAM - CGCGATCACTCCGTGCCAGCAGCCGCGGATCGCG - BHQ1 (Chiba, et al., 2009). The Amplification procedure was: $95^{\circ} \mathrm{C}$ for $2 \mathrm{~min}\left(95^{\circ} \mathrm{C}\right.$ for $15 \mathrm{sec}, 55^{\circ} \mathrm{C}$ for $30 \mathrm{sec}, 72^{\circ} \mathrm{C}$ for $30 \mathrm{~s}$ ) 50 cycles.

Additionally, in every sample of DNA isolated from blood, $\beta$-actin gene detection was performed in the presence of EvaGreen dye (Biotium) in order to check whether rtPCR inhibition takes

e-mail: tomasz.gosiewski@uj.edu.p

Abbreviations: $B S A$, bovine serum albuminum; $C_{T}$ reaction cycle number, in which linear increase of the product cuts the established baseline; $I / I_{O}$, expressed by the relative fluorescence unit, RFU, taken in the last, 40th, reaction cycle to the efficiency of the control reaction without heme $(I)$; RFU level in the 40th reaction cycle $\left(I_{0}\right)$; RFU, relative fluorescence unit; SSA, sheep serum albuminum 
place: (F) GCCAGTGCCAGAAGAGCCAA, (R) TTAGGGTTGCCCATAACAGC (Valle et al., 2010). Amplification procedure was as follows: $95^{\circ} \mathrm{C}$ for $5 \mathrm{~min}$ $\left(95^{\circ} \mathrm{C}\right.$ for $30 \mathrm{sec}, 55^{\circ} \mathrm{C}$ for $30 \mathrm{sec}, 72^{\circ} \mathrm{C}$ for $\left.1 \mathrm{~min}\right) 30$ cycles and final extension at $72^{\circ} \mathrm{C}$ for $5 \mathrm{~min}$.

DNA purity and concentration evaluation. The concentration and purity of $E$. coli DNA was measured spectrophotometrically at wavelengths of 260 and 280 $\mathrm{nm}$. Heme concentration in the samples was measured at a wavelength of $388 \mathrm{~nm}$ (Lomabrdo et al., 2005). The measurement was performed in the NanoDrop machine (Thermo Scientific) in isolates obtained from whole blood and subjected to preliminary processing.

Evaluation of the influence of heme on the activity of thermostable DNA polymerases. Six thermostable DNA polymerases $(0.3 \mathrm{U})$ with 5 ' to 3 ' exonuclease activity were studied: JumpStart Taq (Sigma); Hybrid (EURx); Perpetual Taq (EURx); Tf (EURx); Tth (EURx); Tbr (FINNZYMES). The study consisted in the amplification of $1 \mu \mathrm{l}(2.5 \mathrm{ng} / \mathrm{ml})$ E. coli DNA with the use of DNA polymerases in heme gradient $(0 \mathrm{mM}-1.0$ $\mathrm{mM}$ ). The amplification was carried out in the volume of $10 \mu \mathrm{l}$. The composition of the reaction mixture is given in table 1 . The measure of enzyme activity [I/ $I_{O}$ ] was the ratio of the reaction of the studied sample in a given heme concentration, ( $I$ - expressed by the relative fluorescence unit, RFU, taken in the last, 40th, reaction cycle) to the efficiency of the control reaction without heme $I_{O}-$ RFU level in the 40th reaction cycle). For each of the studied enzymes, determination was performed six times.

Evaluation of the influence of protective substances on the sensitivity and efficiency of DNA amplification.: The impact of seven substances (in concentration gradient of $0 \%-2 \% \mathrm{w} / \mathrm{v}$ ) was analyzed as regards the sensitivity and efficiency of E. coli DNA amplification reaction; these were: bovine albumin (BSA) (Sigma), sheep albumin (SSA) (Sigma), betaine (Sigma), DMSO (Sigma), glycogen (Sigma), dextran (Sigma), Triton X-100 (Sigma). Amplification was conducted with the use of the polymerase, which proved to be the most resistant to heme inhibition. The reaction mixture $(10 \mu \mathrm{l})$ consisted of the studied protective substance, $1 \mu \mathrm{l}(2.5 \mathrm{ng} /$ $\mathrm{ml})$ E. coli DNA, the components quoted in table 1 and heme in the concentration of $0.25 \mu \mathrm{M}$ (Sigma). Amplification efficiency was determined as the relation of the fluorescence signal intensity of the studied sample, taken in the last, 40th, reaction cycle, to the control sample fluorescence (without any protective substance). Amplification sensitivity was defined as the relation of the $C_{T}$ value (reaction cycle number, in which linear increase of the product cuts the established baseline at $30 \mathrm{RFU}$ ) for the studied sample to the $C_{T}$ value for the control sample, which does not contain any protective compound. Determination was performed six times.

Statistics. In the statistical analysis, Levene's test was applied, in order to confirm the equality of variances, followed by an ANOVA test. Significant differences were established to be of statistical significance of $p<0.05$. All calculations were conducted using Gratel software ver. 1.9.4.

\section{RESULTS}

\section{Evaluation of the influence of heme on the activity of thermostable DNA polymerases}

The activity of six themostable DNA polymerase enzymes was investigated in the presence of an increasing

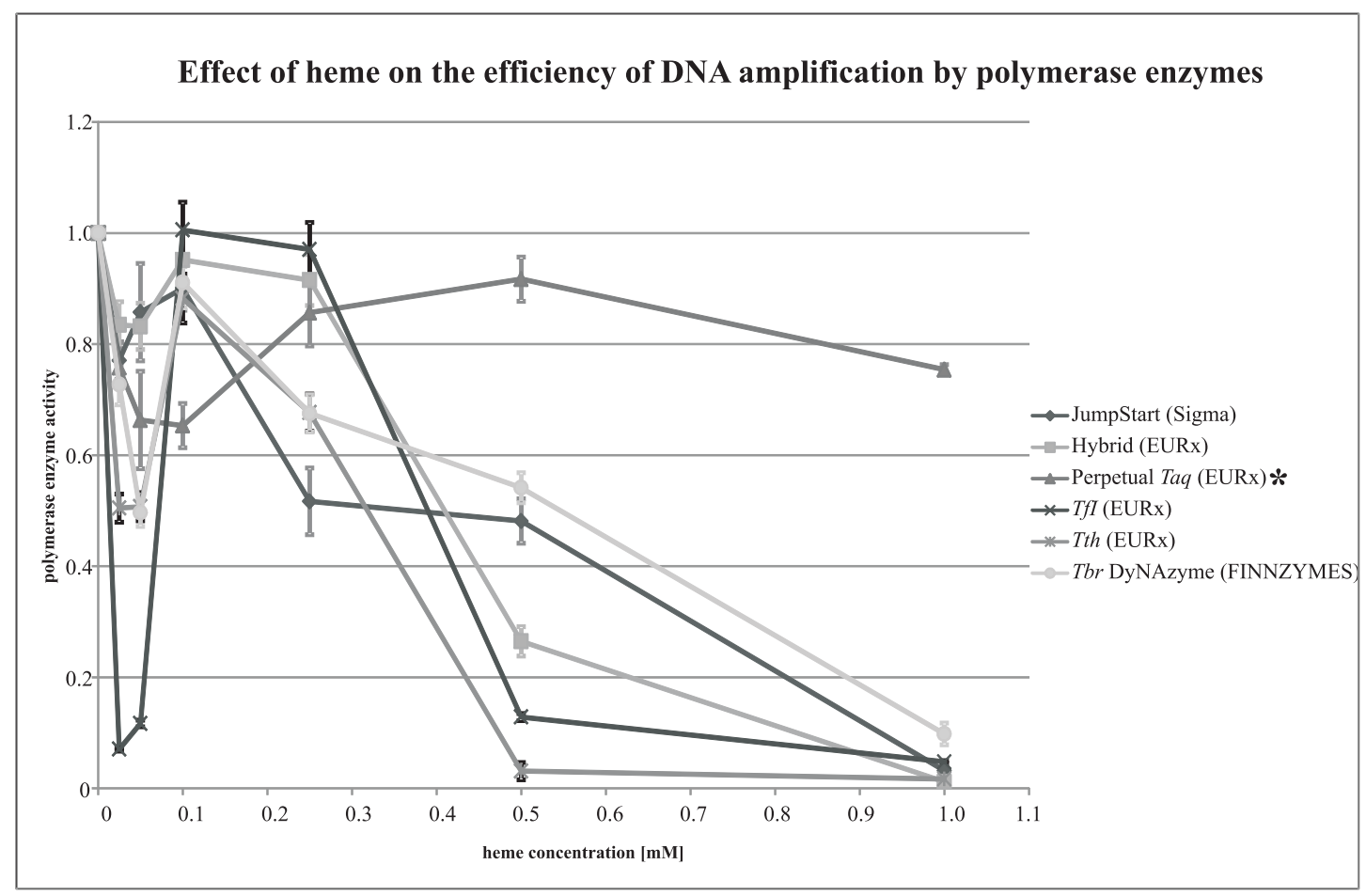

Figure 1. Comparison of the influence of heme gradient on the activity of thermostable polymerase enzymes with exonuclease activity $\left(5^{\prime}-3^{\prime}\right)$

*enzyme activity significantly different from the remaining studied ones in each measuring point; $\left[I / I_{0}\right]-$ the measure of enzyme activity ( $I$ - expressed by the relative fluorescence unit (RFU) of the studied sample, taken in the last, 40th, reaction cycle, in a given heme concentration; $I_{0}$ - RFU level in the 40th reaction cycle (without heme)). 


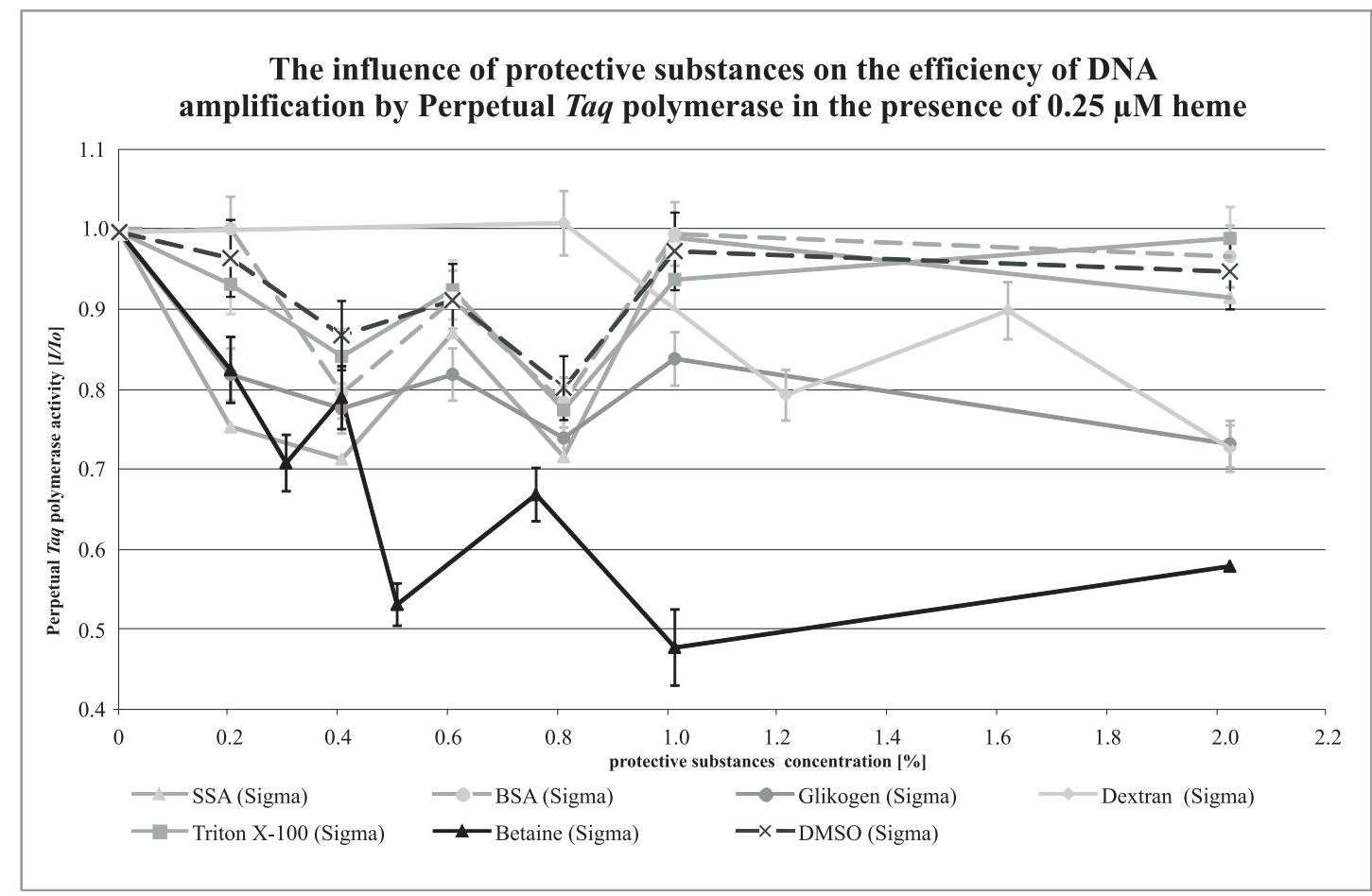

Figure. 2. Comparision of the influence of protective substances on the efficiency of DNA amplification by Perpetual Taq polymerase in the presence of $0.25 \mu \mathrm{M}$ of heme

$\left.1 / I_{0}\right]$ - the measure of enzyme activity ( $I$ - expressed by the relative fluorescence unit (RFU) of the studied sample, taken in the last, 40 th, reaction cycle; $I_{0}-$ RFU level in the 40 th reaction cycle (without any protective substance)).

Table 1. Reaction mixtures $(10 \mu \mathrm{l})$ composition for the study of heme influence on the activity of thermostable DNA polymerases.

\begin{tabular}{|c|c|c|c|}
\hline Polymerase studied & Buffer (10x) & $\mathrm{MgCl}_{2}[\mathrm{mM}]^{*}$ & Other components \\
\hline Taq (Sigma) & Kit component & 6.5 & $\begin{array}{l}\text { Starter }(F)[200 \mathrm{nM}] \\
\text { Starter }(\mathrm{R})[200 \mathrm{nM}] \\
\text { E. coli }[300 \mathrm{nM}] \text { probe }\end{array}$ \\
\hline Hybrid (EURx) & Buffer B (EURx) & 6.5 & \multirow{5}{*}{$\begin{array}{l}\text { dNTP (EURx) }[200 \mu \mathrm{M}] \\
\text { Starter (F) }[200 \mathrm{nM}] \\
\text { Starter (R) }[200 \mathrm{nM}] \\
\text { E. coli }[300 \mathrm{nM}] \text { probe } \\
\text { DNA matrix of the studied microbe }[1 \mu \mathrm{l}]\end{array}$} \\
\hline Perpetual Taq (EURx) & Buffer B (EURx) & 7.75 & \\
\hline$T f(E \cup R x)$ & Buffer B (EURx) & 6.5 & \\
\hline Tth (EURx) & Buffer B (EURx) & 10.25 & \\
\hline Tbr (FINNZYMEs) & Tbr buffer (FINNZYMEs) & 9.0 & \\
\hline
\end{tabular}

*Total concentration of magnesium chloride, taking into account the concentration in polymerase buffer

concentration of heme $(0-1.0 \mathrm{mM})$ in a sample subjected to amplification. Perpetual Taq (EURx) polymerase maintained the highest activity, which did not fall below $0.65\left[I / I_{O}\right]$, and this result was significantly different $(p<0.001)$ from other studied polymerases. The remaining enzymes decreased their activity to the level of zero if the highest concentration of heme was applied, i.e. 1.0 $\mathrm{mM}$, while Tth (EURx) polymerase was completely inactivated in the presence of only $0.5 \mathrm{mM}$ heme (Fig. 1).

\section{Evaluation of the concentration of heme in DNA samples isolated from blood}

A measurement of the concentration of heme was also performed in the DNA samples obtained from human blood. The procedure of DNA isolation using the GeneMATRIX Quick Blood DNA Purification Kit (EURx) allowed for obtaining the level of heme concentration of $2.76( \pm 2.23) \mu \mathrm{M}$ in DNA isolates.
Evaluation of the influence of protective substances on the sensitivity and efficiency of DNA amplification

The influence of seven substances on the sensitivity and efficiency of amplification reaction was tested. The reaction was conducted with the use of Perpetual Taq (EURx) polymerase, which proved to be the most resistant to the activity of heme. The PCR reaction was conducted in the presence of $0.25 \mu \mathrm{M}$ heme, which constituted a tenfold lower concentration than the average determined in the DNA isolates obtained with the use of the GeneMATRIX Quick Blood DNA Purification Kit (EURx) while applying the procedure of blood samples. A tenfold dilution of heme was necessary, as the DNA samples were diluted in the reaction mixture.

The analysis of results showed that both the sensitivity and efficiency of the amplification reaction were lower than in the control sample (without the addition of a 
protective substance) in the case of each of the studied substances in full concentration range (Fig. 2).

\section{DISCUSSION}

The main difficulty in performing PCR analysis of blood samples stems from the fact that blood is rich in hemoglobin, which contains heme, a strong inhibitor of DNA polymerases catalyzing the DNA amplification process (Akane et al., 1994; Al-Soud \& Radstrom, 2001).

Thermostable DNA polymerases employed in the PCR method are characterized by various sensitivity to inhibitors. Blood, as a diagnostics material containing a large number of inhibitors, among which the most prominent is heme, constitutes a considerable problem in molecular diagnostics (Al-Soud \& Radstrom, 2001). It is impossible to completely avoid the contamination of DNA isolates with heme, but it is feasible to determine the resistance of particular polymerases to inhibition by heme. Such attempts have been undertaken by Al-Soud et al. (1998) who, despite the fact that they have employed the classic PCR method and their result analysis was based on a semi-quantitative assessment of amplification product quantity on an electrophoretic gel, succeeded in demonstrating the heterogeneity of polymerases with respect to resistance to heme (Al-Soud \& Lantz, 1998). Real-time PCR was applied in our experimental model with the use of a TaqMan probe, therefore we have studied polymerases with (5'-3') exonuclease activity, allowing probe degradation and fluorophore activation. Opel et al. (2010) have conducted a similar test, in which they have determined the impact of the increasing concentration of heme on the effectiveness of DNA amplification with the use of Ramp Taq. (Denville Scientific) polymerase; however, they were using SYBR Green I dye instead of the TaqMan probes (Opel et al., 2010). They have concluded that the increasing concentration of heme correlated positively with the decrease of the amplification sensitivity, which confirms the results of our research. It should be noted that the range of heme concentration studied by Opel et al. (2010) (1.5-3 $\mu \mathrm{M})$ did not overlap with the one applied by us (0-1 mM) (Opel et al., 2010). The difference stemmed from the fact that the method of DNA isolation used in this study allowed us to obtain a medium concentration of heme in the isolated sample at the level of $2.76 \mu \mathrm{M}$, therefore, in the sample subjected to amplification, it was $0.25 \mu \mathrm{M}$. Furthermore, our study had the advantage of encompassing several different polymerases, out of which Perpetual Taq proved to be the least sensitive to heme activity.

The impact of compounds having a protective effect on the Perpetual Taq (EURx) polymerase enzyme was also studied. The presence of a substance with a potential protective effect correlated negatively with both the sensitivity and the efficiency of the amplification reaction. The obtained results do not confirm the observa- tions of other authors, who recommend the application of polymerase enzyme protectors (Kreader, 1996). It is possible that the molecular structure of the studied polymerase endows it with high resistance to heme while the addition of supplementary substances intensifies the inhibitory effect. A conclusion can be drawn that the Perpetual Taq (EURx) polymerase is the most resistant to the inhibitory effects of heme and does not require any protective substances, which simplifies the preparation of the reaction mixture and decreases the costs and the risk of contamination. Selection of the appropriate polymerase can increase the efficiency of the PCR reaction which is very important for diagnosis of sepsis and for other analyses performed on DNA template isolated from the blood.

\section{Ethics}

The research was granted approval by the local Bioethics Committee of the Jagiellonian University (KBET/94/B/2009).

\section{Acknowledgements}

This study was supported by the Polish Ministry of Science and Higher Education within the framework of project grant N N401 006739.

Language translation: Katarzyna Gąsior-Kulasiak.

\section{REFERENCES}

Abu Al-Soud W \& Radstrom P (1998) Capacity of nine thermostable DNA Polymerases to Mediate DNA Amplification in the Presence of PCR - Inhibiting Samples. Appl. Environ. Microbiol 64: 3748-3753.

Abu Al-Soud W \& Radstrom P (2001) Purification and Characterization of PCR-Inhibitory Components in Blood Cells. J Clin Microbiol 39: 48-493.

Abu Al-Soud W, Lantz P, Backman A, Olcen P \& Radstorm P (1998) A sample preparation method which facilitates detection of bacteria in blood cultures by the polymerase chain reaction. J Microbiol Methods 32: $217-224$.

Akane A, Matsubara K, Nakamura H, Takahashi S \& Kimura K (1994) Identification of the Heme Compound Copurified with Deoxyribonucleic Acid (DNA) from Bloodstains a Major Inhibitor of Polymerase Chain Reaction Amplification. J Forensic Sci 39: 362-372.

Chiba N, Murayama SY, Morozumi M, Nakayama E, Okada T, Iwata S, Sunakawa K, Ubukata K (2009) Rapid detection of eight causative pathogens for the diagnosis of bacterial meningitis by real-time PCR. I Infect Chemother 15: 92-98.

Klouche M \& Schroder U (2008) Rapid Methods for Diagnosis of Bloodstream Infections. Clin Chem Lab Med 46: 888-908.

Kreader CA (1996). Relief of Amplification Inhibition in PCR with Bovine Serum Albumin or T4 Gene 32 Protein. Appl Environ Microbiol 62: 1102-1106.

Lombardo ME, Araujo LS, Ciccarelli AB \& Batlle A (2005) A Spectrophotometric Method for Estimating Hemin in Biological Systems. Anal Biochem 341: 199-203.

Opel KL, Chung D \& McCord BR (2010) A Study of PCR Inhibition Mechanisms Using Real Time PCR. J Forensic Sci 55: 25-33.

Valle Jr DL, Andrade JI, Cabrera EC \& Rivera WL (2010) Evaluation of Buffy Coat 16s rRNA PCR, Buffy Coat Culture and Whole Blood PCR for Detection of Bacteraemia. Mem Inst Oswaldo Cruz. 105: $117-122$. 